\title{
THE COLLAGEN STATE WITHIN THE PARCHMENT AFTER INFLUENCE OF ARTIFICIAL AGING
}

\author{
Nataliia RAKSHA ${ }^{1}$, Tetiana HALENOVA ${ }^{1}$, Tetiana VOVK ${ }^{1}$, Olexiy SAVCHUK ${ }^{1}$, Olga ANDREYEVA ${ }^{2}$, Anna \\ NIKONOVA ${ }^{2}$, Tetiana KOLESNYK ${ }^{2}$
}

${ }^{1}$ ESC “Institute of Biology and Medicine" of Taras Shevchenko National University of Kyiv, 64/13, Volodymyrska Str., Kyiv, 01601, Ukraine, olexiy.savchuk@ukr.net

${ }^{2}$ Kyiv National University of Technologies and Design, 2, Nemirovich-Danchenko Str., Kyiv, 01011, Ukraine, annavnikonova@ gmail.com

Received: 31.01.2019

Accepted: 14.06 .2019

https://doi.org/10.24264/Ifj.19.2.6

\section{THE COLLAGEN STATE WITHIN THE PARCHMENT AFTER INFLUENCE OF ARTIFICIAL AGING}

ABSTRACT. The study examines the influence of artificial aging on the stability of collagen within the parchments. Aging of the parchments was generated by heating at $70^{\circ} \mathrm{C}$ in a dry oven for $72 \mathrm{~h}$ as well as by keeping the parchment samples in the solution of artificial sweat. Sodium dodecyl sulfate polyacrylamide gel electrophoresis and size-exclusion chromatography were utilised to investigate the state of proteins within the parchment samples after exposure to heating and artificial sweat. The study has shown that the accelerated aging of the parchment results in marked change of protein and peptide concentrations, release of collagen chains, as well as leads to the alteration in the peptide compositions.

KEY WORDS: parchment, collagen, accelerated aging, electrophoresis, chromatography

STAREA COLAGENULUI DIN PERGAMENT SUB INFLUENTA ÎMBĂTRÂNIRII ARTIFICIALE

REZUMAT. Studiul examinează influenţa îmbătrânirii artificiale asupra stabilităţii colagenului din pergamente. Pergamentele au fost îmbătrânite prin încălzirea la $70^{\circ} \mathrm{C}$ într-un cuptor uscat timp de 72 de ore, precum şi prin menţinerea probelor de pergament în soluţia de transpiraţie artificială. S-au utilizat electroforeza în gel de dodecil sulfat de sodiu-poliacrilamidă şi cromatografia de excludere a mărimii pentru a investiga starea proteinelor din probele de pergament după expunerea la încălzire şi transpiraţie artificială. Studiul a arătat că îmbătrânirea accelerată a pergamentului are ca rezultat o schimbare vizibilă a concentraţiilor de proteine şi peptide, eliberarea lanţurilor de colagen, precum şi modificarea compoziţiilor peptidice.

CUVINTE CHEIE: pergament, colagen, îmbătrânire accelerată, electroforeză, cromatografie

L'ETAT DE COLLAGENE DANS LE PARCHEMIN SOUS L'INFLUENCE DU VIEILLISSEMENT ARTIFICIEL

RÉSUMÉ. L'étude examine l'influence du vieillissement artificiel sur la stabilité du collagène dans les parchemins. Les parchemins ont été vieillis par chauffage à $70^{\circ} \mathrm{C}$ dans un four sec pendant 72 heures, ainsi que par conservation des échantillons de parchemin dans la solution de transpiration artificielle. L'électrophorèse en gel de polyacrylamide contenant du dodécysulfate de sodium et la chromatographie d'exclusion stérique ont été utilisées pour étudier l'état des protéines dans des échantillons de parchemin après une exposition au chauffage et à la transpiration artificielle. L'étude a montré que le vieillissement accéléré du parchemin entraînait un changement visible des concentrations de protéines et de peptides, la libération de chaînes de collagène et une modification des compositions de peptides.

MOTS CLÉS: parchemin, collagène, vieillissement accéléré, électrophorèse, chromatographie

\section{INTRODUCTION}

Parchment is an important biomaterial that has been used for cultural artifacts and household objects [1, 2]. Although parchment is an incredibly stable material it inevitably changes over time which can cause alteration in its physical properties. Aging of parchment can be accelerated by a range of environmental (temperature, humidity), biological (bacterial, fungal growth) as well as physical (mechanical, radiation damage) factors [3]. All of these factors, alone or synergistically, are capable of altering the chemistry of the collagen molecules that leads to destabilization of the native conformation of parchment objects and generates different types of deteriorations over time. Heat-induced aging and action of artificial sweat are among the factors that imitate the influence which the parchment can undergo during extensive exploitation.

For today, some destructive and nondestructive techniques are applied for investigation of parchment state [4-6]. However, development and implementation of new simple methodological approaches based on analysis of the structure of protein component 
within the parchment might be useful for more complete characteristic of parchment state. This paper examines the application of biochemical techniques with the purpose to improve diagnostic tools for estimation collagen integrity within the parchment. The long-term heating and artificial sweat action were applied as agents for acceleration wear of parchment samples.

\section{EXPERIMENTAL}

\section{Materials and Methods}

\section{Materials}

Our experiments were carried out on sheep parchments that were manufactured by several methods of liming. There were 4 experimental groups based on the method used for the parchment preparation: the group 1 - the parchment for restoration work was manufactured according to the method [7], which involves two-stage liming with consumption of calcium hydroxide up to $35 \mathrm{~g} / \mathrm{L}$; the group 2 - the parchment for writing was manufactured according to the method [8], which involves two-stage liming with consumption of calcium hydroxide up to $26 \mathrm{~g} / \mathrm{L}$; the group 3 the transparent parchment was manufactured according to the ancient method [9] by sulphidelimy method; the group 4 - the parchment for general purpose was manufactured by accelerated method of oxidative liming [10]. The finishing processes and operations for experimental groups of parchments was executed by drying, surface grinding as well as plasticization; in addition, the bleaching was carried out in the groups 2 and 3 while the filling with potassium aluminum salt was performed in the group 3 [11-12]. The artificial aging of the parchments was done as described below. Heat-induced aging was imitated by keeping the parchment samples in the laboratory chamber at $70^{\circ} \mathrm{C}, 0 \% \mathrm{rH}$ for $72 \mathrm{~h}$. Sweat resistance test was carried out by keeping the parchment samples in the solution of artificial sweat $(\mathrm{NaCl}$ $0.2 \%(w / w),\left(\mathrm{NH}_{4}\right)_{2} \mathrm{CO}_{3}(0.07 \%), \mathrm{Na}_{2} \mathrm{HPO}_{4}(0.02 \%)$, carbamide $(2.4 \%)$, lactic acid $(0.13 \%)$ at $25^{\circ} \mathrm{C}$ for
$72 \mathrm{~h}$ [13]. Afterwards, the samples were dried at room temperature for $24 \mathrm{~h}$. After been dried, the parchment was cut into small pieces $(0.3 \times 0.3 \mathrm{~cm})$ with scissors. A piece was put into distilled water (1:10 weight/volume) and left for $2 \mathrm{~h}$ at $90^{\circ} \mathrm{C}$ in a thermostat. Then the solution was centrifuged at $600 \mathrm{rpm}$ for 15 minutes. The residue was discarded and obtained solution was used for further analysis.

\section{Protein Concentration Determination}

The concentration of protein was determined according to the method described by [14] using crystalline bovine serum albumin as the standard protein and measuring the absorbance at $595 \mathrm{~nm}$.

\section{Peptide Fractions Isolation}

The peptide fractions were obtained according to [15]. The aliquot of the solutions after soaking of the parchment fragments were mixed with $1.2 \mathrm{M} \mathrm{HClO}_{4}$ at $1: 1(\mathrm{v} / \mathrm{v})$ ratio in order to precipitate the proteins. After centrifugation (20 $\mathrm{min}, 5000 \mathrm{~g}, 4^{\circ} \mathrm{C}$ ) the supernatants were neutralized by $5 \mathrm{M} \mathrm{KOH}$ to $\mathrm{pH} 7.0$ and the samples were subjected to centrifugation step again. Ethanol was added to the final concentration of $80 \%$, the samples were kept at $4^{\circ} \mathrm{C}$ for $30 \mathrm{~min}$ and after final centrifugation the concentration of peptides was determined in the supernatant by measuring the absorbance at $210 \mathrm{~nm}$.

\section{Size-exclusion Chromatography}

The peptide fraction was applied to size exclusion chromatography on Sephadex G-15 column (Bio Rad, USA) pre-equilibrated with $0.05 \mathrm{M}$ Tris- $\mathrm{HCl}, \mathrm{pH} 7.4$ containing $0.13 \mathrm{M} \mathrm{NaCl}$. The samples were loaded and the peaks were collected at a flow rate of $30 \mathrm{~mL}$ per hour. The areas under the peaks of chromatographic curves were calculated using the OriginLab (v 9.1). The molecular weight of peptides was estimated using calibration curve. For this purpose, the column was previously calibrated with standard marker solution (lysozyme, $14.3 \mathrm{kDa}$; insulin, $5.7 \mathrm{kDa}$; vitamin B12, $1.35 \mathrm{kDa}$ ) [16]. 
Sodium Dodecyl Sulfate Polyacrylamide Gel

Electrophoresis (SDS-PAGE)

SDS-PAGE was done using the Laemmli system as described by [17]. The stacking and separating gels were $4 \%(w / v)$ and $8 \%(w / v)$, respectively. Samples were concentrated by trichloroacetic acid; the obtained precipitates were twice washed with acetone, dried at $37^{\circ} \mathrm{C}$ and then dissolved in SDS-PAGE buffer $(5 \mathrm{mM}$ Tris- $\mathrm{HCl}, \mathrm{pH} 8.3$ containing 2\% SDS, 5\% sucrose, and $0.02 \%$ bromophenol blue). SDS-PAGE was performed using Mini-Protean Tetra System (Bio Rad, USA) at $19 \mathrm{~mA}$ for stacking gel and 36 $\mathrm{mA}$ for separating gel. The amount of protein applied to the gel was $20 \mu \mathrm{g}$ per line. After electrophoresis was done, the gels were stained with 2.5\% Coomassie brilliant blue R-250 in 10\% $(\mathrm{v} / \mathrm{v})$ ethanol, $10 \%(\mathrm{v} / \mathrm{v})$ acetic acid, $15 \%(\mathrm{v} / \mathrm{v})$ isopropanol and the background of the gel was destained with $7 \%(\mathrm{v} / \mathrm{v})$ acetic acid for $30 \mathrm{~min}$. The electrophoregrams were analyzed using the program TotalLab ( $v$ 2.01). The molecular weights of proteins were estimated based on MW standard (myosin, $200 \mathrm{kDa} \beta$-galactosidase, $116.2 \mathrm{kDa}$; phosphorylase b, $97.4 \mathrm{kDa}$; bovine serum albumin, $66 \mathrm{kDa}$; ovalbumin, $45 \mathrm{kDa}$; carbonic anhydrase, $31 \mathrm{kDa}$; trypsin inhibitor, 21.5 kDa (Bio Rad, USA)).

\section{Statistical Analysis}

The results were reported as mean \pm SEM $(n=5)$. Statistical analysis was performed using one-way analysis of variance (ANOVA). Differences were considered to be statistically significant when $p<0.05$.

\section{RESULTS AND DISCUSSIONS}

Parchment is predominantly composed of collagen type I that is a heterotrimeric molecule consisting of three polypeptide chains, namely two $\alpha 1$-chains and one $\alpha 2$-chain [18]. These chains are organized into fibrils, which are, in turn, grouped into fibers. Over time, collagen molecules could lose their structural stability, which is accompanied by decreasing of mechanical properties of the parchment objects [19]. Similar to other biomaterials parchment is sensitive to the environmental conditions which in case of sudden and significant changes accelerate aging of the parchments. In the current study we have investigated collagen integrity of the parchment samples after the influence of both long-term heating and artificial sweat using methods of protein biochemistry.

At first, we determined the concentration of protein in solution obtained after soaking of the parchment samples. It has been shown the least concentration of protein in the group 2 under control condition (Table 1) which is most likely mediated by higher stability of protein molecules within the parchment. The highest concentration of protein has been detected in the control sample of the group 3 . This result might indirectly indicate the partial destruction of proteins during the manufacturing process.

The influence of heating and artificial sweat leads to multidirectional change of the protein concentration. The significant increase of protein concentration (the group 1 under long-term heating and artificial sweat action; the group 2 under artificial sweat action; the group 4 under long-term heating) as well as the decrease of protein concentration (the group 3 and the group 4 under artificial sweat action; the group 2 under long-term heating) was shown.

Table 1: Protein concentration $\left(\mathrm{mg} \cdot \mathrm{mL}^{-1}\right)$ in the solution obtained after soaking of the parchment samples

\begin{tabular}{ccccc}
\hline Condition & Group 1 & Group 2 & Group 3 & Group 4 \\
\hline Control & $5.50 \pm 0.38$ & $3.75 \pm 0.26$ & $8.00 \pm 0.56$ & $7.00 \pm 0.49$ \\
Long-term heating & $13.25 \pm 0.92 *$ & $1.62 \pm 0.11^{*}$ & $7.37 \pm 0.51$ & $9.37 \pm 0.65^{*}$ \\
Artificial sweat action & $10.37 \pm 0.72 *$ & $4.50 \pm 0.31 *$ & $6.25 \pm 0.43^{*}$ & $3.62 \pm 0.25^{*}$ \\
\hline
\end{tabular}

Values are expressed as mean \pm SEM $(n=5) ;{ }^{*} p<0.05$ significantly different from the control 
The changes of protein concentration can be explained by destabilizing of collagen structure and releasing collagen chains or/and collagen fragments into solution. In order to analyze the qualitative composition of proteins with respect to the presence of collagen fragments, the SDSPAGE technique was applied. The results of electrophoretic analysis of the solution obtained after soaking of the parchment samples are presented in Table 2.

Table 2: Results of electrophoretic analysis of the solution obtained after soaking of the parchment samples

\begin{tabular}{|c|c|c|c|c|c|}
\hline & Condition & $\begin{array}{l}\text { Dimmer of } \alpha \text {-chains of } \\
\text { collagen }(>200 \mathrm{kDa}), \%\end{array}$ & $\begin{array}{c}\alpha 1 \text {-chains of collagen } \\
(110 \mathrm{kDa}), \%\end{array}$ & $\begin{array}{c}\alpha 2 \text {-chains of collagen } \\
(100 \mathrm{kDa}), \%\end{array}$ & $\begin{array}{l}\text { Fragments of collagen } \\
(<100 \mathrm{kDa}), \%\end{array}$ \\
\hline \multirow{3}{*}{$\begin{array}{l}-1 \\
\frac{1}{5} \\
0 \\
\frac{0}{0}\end{array}$} & Control & 25 & 73 & 2 & - \\
\hline & $\begin{array}{l}\text { Long-term } \\
\text { heating }\end{array}$ & 27 & 73 & - & - \\
\hline & $\begin{array}{l}\text { Artificial } \\
\text { sweat action }\end{array}$ & 59 & 37 & 2 & 2 \\
\hline \multirow{3}{*}{$\begin{array}{l}N \\
\frac{2}{5} \\
0 \\
0\end{array}$} & Control & 13 & 54 & 7 & 26 \\
\hline & $\begin{array}{l}\text { Long-term } \\
\text { heating }\end{array}$ & 20 & 63 & 3 & 14 \\
\hline & $\begin{array}{l}\text { Artificial } \\
\text { sweat action }\end{array}$ & 30 & 48 & 9 & 13 \\
\hline \multirow{3}{*}{$\begin{array}{l}m \\
\frac{0}{5} \\
0 \\
\text { லे }\end{array}$} & Control & 22 & 64 & 6 & 8 \\
\hline & $\begin{array}{l}\text { Long-term } \\
\text { heating }\end{array}$ & 26 & 64 & 7 & 3 \\
\hline & $\begin{array}{l}\text { Artificial } \\
\text { sweat action }\end{array}$ & 58 & 33 & 3 & 6 \\
\hline \multirow{3}{*}{$\begin{array}{l}\nabla \\
\frac{a}{2} \\
0 \\
\frac{0}{0}\end{array}$} & Control & 14 & 84 & 2 & - \\
\hline & $\begin{array}{l}\text { Long-term } \\
\text { heating }\end{array}$ & 15 & 83 & 2 & - \\
\hline & $\begin{array}{l}\text { Artificial } \\
\text { sweat action }\end{array}$ & 4 & 47 & 19 & 30 \\
\hline
\end{tabular}

SDS-PAGE analysis has revealed the presence of $\alpha 1$-chains of collagen, the content of which was much higher comparing to the content of $\alpha 2$-chains. The appearance of both $\alpha$-chains might be due to disorder of native structure of the parchment and extraction of collagen fragments into solution. In general, the influence of artificial sweat on parchment samples was more damaging as it provoked the release of big collagen fragments, namely dimmers of $\alpha$-chains. The accumulation of dimmers is an unfavorable sign as it indicates the changes at the level of collagen triple helix. Moreover, loss of big fragments would potentially lead to decrease of mechanical properties of the parchment during its intensive exploitation in the future. In contrast, the influence of artificial sweat provoked significant disturbances in ordered collagen structure in the group 4 . As a result, collagen chains were disintegrated into fragments with molecular weights less than 100 kDa.

Taking into account that the structure of collagen is stabilized by hydrogen bonds [20], long-term heating might provoke break down of collagen molecules into individual chains by affecting hydrogen bonds within collagen fibers. Changes of water content caused by longterm heating of the parchment samples also might provoke the structural alteration of the arrangement of collagen chains at molecular and supramolecular levels. This finding is based on well-known fact that integrity of collagen triple helix is in part due to the formation of water bridges, which act as a stabilizing factor in holding collagen chains together [21].

Depending on the strength and type of damaging agent, the destruction of collagen 
molecules could be accompanied not only by releasing of individual chains, long protein fragments but also the appearance of peptides. In order to clarify the possible mechanisms of collagen disruption the solution obtained after soaking of the parchment samples was analyzed on the presence of peptides. According to the data, the significant increase of the peptide fraction level has been observed in the group 1 and 4 under experimental conditions (Table 3). We suppose the accumulation of peptides could be considered as by-effect of release of dimmers (the group 1) or cleavage of collagen into lower molecular weight fragments (the group 4).

Table 3: Level of peptides $\left(\mathrm{r} . \mathrm{u} \cdot \mathrm{mL}^{-1}\right)$ in the solution obtained after soaking of the parchment samples

\begin{tabular}{lcccc}
\hline Condition & Group 1 & Group 2 & Group 3 & Group 4 \\
\hline Control & $1.19 \pm 0.09$ & $2.16 \pm 0.14$ & $3.29 \pm 0.22$ & $0.32 \pm 0.02$ \\
Long-term heating & $3.76 \pm 0.25^{*}$ & $0.19 \pm 0.01^{*}$ & $2.00 \pm 0.16^{*}$ & $0.71 \pm 0.04 *$ \\
Artificial sweat action & $2.38 \pm 0.16^{*}$ & $1.28 \pm 0.08^{*}$ & $1.86 \pm 0.13^{*}$ & $2.77 \pm 0.19 *$ \\
\hline
\end{tabular}

Values are expressed as mean \pm SEM $(n=5) ;{ }^{*} p<0.05$ significantly different from the control

On the other hand, the changes in the peptide content might be the result of action of lipid radicals. It is well-known that additionally to collagen fibres, the parchment includes lipids [22], the qualitative and quantitative composition of which depend on the method of processing the skin at the stage of parchment manufacture. It has been established [23] that lipids presented in the parchment samples, might interact with the collagen possibly contributing to the degradation of parchment. Lipids influence the collagen structure, probably via autoxidation of lipids and accumulation of highly reactive peroxidation products.

The decrease of the peptide level in the groups 2 and 3 under long-term heating and artificial sweat action has been found (Table 3). This observation is fully consistent with our previous data regarding the protein concentration in these groups.

The analysis of the qualitative composition of peptide fraction could be useful to provide additionalinformationaboutthecollagen integrity and as a consequence about the mechanical resistance of the parchment. The more longsize peptides are released from the parchment, the less the parchment will be persistent to the damages. Size-exclusion chromatography was applied to estimate the presence of peptides of different molecular weights. The comparison of the results of chromatographic analysis of peptide fractions obtained after exposure of the parchment samples to long-term heating and action of artificial sweat (Table 4) has revealed that they were similar in terms of number of peaks and distribution of peptides among the peaks. In general, the influence of these factors has resulted in the increase of peak numbers as well as the appearance of low-size peptides compared to the control samples.

As can be seen from Table 4, the majority of peptides detected after influence of longterm heating and artificial sweat action were molecules with molecular weight up to $1 \mathrm{kDa}$ which correspond to peptide length less than the 10 amino acids. 
Table 4: Results of chromatographic analysis of the peptide fractions

\begin{tabular}{|c|c|c|c|c|c|}
\hline & & $\begin{array}{c}\text { General area under peaks } \\
\text { (r.u) }\end{array}$ & Number of peaks & Molecular weight (Da) & Area under peak (r.u) \\
\hline \multirow{11}{*}{$\begin{array}{l}-1 \\
\frac{1}{3} \\
0 \\
0\end{array}$} & \multirow[t]{3}{*}{ Control } & \multirow[t]{3}{*}{1.4} & 1 & 1881 & 1.4 \\
\hline & & & 1 & 1202 & 3.3 \\
\hline & & & 2 & 1016 & 5.1 \\
\hline & \multirow{5}{*}{ Long-term heating } & \multirow{5}{*}{16.9} & 3 & 780 & 4.9 \\
\hline & & & 4 & 635 & 1.2 \\
\hline & & & 5 & 567 & 1.3 \\
\hline & & & 6 & 482 & 1.1 \\
\hline & & & 1 & 1166 & 1.8 \\
\hline & \multirow{5}{*}{$\begin{array}{l}\text { Artificial sweat } \\
\text { action }\end{array}$} & \multirow{5}{*}{8.4} & 2 & 973 & 3.1 \\
\hline & & & 3 & 755 & 2.4 \\
\hline & & & 4 & 622 & 0.7 \\
\hline \multirow{12}{*}{$\begin{array}{l}\text { N } \\
\frac{2}{3} \\
\frac{0}{1} \\
0\end{array}$} & & & 5 & 558 & 0.4 \\
\hline & & & 1 & 2951 & 1.6 \\
\hline & \multirow[t]{3}{*}{ Control } & \multirow[t]{3}{*}{4.3} & 2 & 1140 & 1.7 \\
\hline & & & 3 & 951 & 0.8 \\
\hline & & & 1 & 1114 & 0.6 \\
\hline & \multirow[t]{3}{*}{ Long-term heating } & \multirow[t]{3}{*}{3.1} & 2 & 987 & 1.6 \\
\hline & & & 3 & 945 & 0.9 \\
\hline & & & 1 & 1162 & 1.9 \\
\hline & \multirow{4}{*}{$\begin{array}{l}\text { Artificial sweat } \\
\text { action }\end{array}$} & \multirow{4}{*}{9.5} & 2 & 957 & 3.7 \\
\hline & & & 3 & 712 & 2.2 \\
\hline & & & 4 & 611 & 0.5 \\
\hline & & & 5 & 547 & 1.3 \\
\hline \multirow{10}{*}{$\begin{array}{l}n \\
\frac{1}{3} \\
0 \\
0 \\
0\end{array}$} & \multirow{4}{*}{ Control } & \multirow{4}{*}{10.0} & 1 & 1116 & 5.8 \\
\hline & & & 2 & 1003 & 4.4 \\
\hline & & & 1 & 1257 & 1.0 \\
\hline & & & 2 & 1010 & 2,4 \\
\hline & \multirow[t]{4}{*}{ Long-term heating } & \multirow[t]{4}{*}{6.9} & 3 & 745 & 1.7 \\
\hline & & & 4 & 625 & 0.4 \\
\hline & & & 5 & 567 & 1.3 \\
\hline & & & 1 & 1596 & 3.7 \\
\hline & \multirow{5}{*}{$\begin{array}{l}\text { Artificial sweat } \\
\text { action }\end{array}$} & \multirow{3}{*}{7.5} & 2 & 1172 & 0.8 \\
\hline & & & 3 & 975 & 1.8 \\
\hline & & & 4 & 728 & 1.2 \\
\hline & & & 1 & 1140 & 0.6 \\
\hline & & & 2 & 963 & 0.7 \\
\hline \multirow{8}{*}{$\begin{array}{l}\checkmark \\
\frac{\sigma}{3} \\
\frac{1}{0} \\
\frac{1}{0}\end{array}$} & \multirow[t]{3}{*}{ Control } & 5.9 & 3 & 758 & 3.5 \\
\hline & & & 4 & 561 & 0.3 \\
\hline & & & 5 & 463 & 0.8 \\
\hline & Long-term heating & 6.0 & 1 & 350 & 6.0 \\
\hline & & & 1 & 1017 & 2.5 \\
\hline & Artificial sweat & $5 ?$ & 2 & 690 & 1.0 \\
\hline & action & 5.2 & 3 & 556 & 0.7 \\
\hline & & & 4 & 444 & 0.6 \\
\hline
\end{tabular}

\section{CONCLUSIONS}

Using the parchment samples obtained by several preparation methods (modern and ancient) we investigated the influence of accelerated aging on protein component of the parchment. The structural integrity of collagen molecules was estimated applying the SDS-PAGE and size-exclusion chromatography.
We can state that these techniques may be employed as additional tools to monitor the degradation of proteins within the parchments. In our findings we have revealed that the most suitable manufacturing technique to maintain the collagen structure was the two-stage method with the use of calcium hydroxide in the concentration up to $26 \mathrm{~g} / \mathrm{L}$ (the group 
2). We have also shown that the damaging effect of long-term heating and artificial sweat action strongly depended on the method of parchment obtaining. Most of the times, the damage of collagen structure produced by action of artificial sweat on parchment was more pronounced. Obtained data contribute to better understanding of the mechanisms of the parchment degradation and could be useful to improve manufacturing process.

\section{REFERENCES}

1. Budrugeac, P., Miu, L., Popescu, C., Wortmann, F.-J., J Therm Anal Calorim, 2004, 77, 3, 975-85, https://doi.org/10.1023/ B:JTAN.0000041673.37722.d6.

2. Bailey, A., Paul, R., J Soc Leath Tech Ch, 1998, 82, 104-110.

3. Abdel-Maksoud, G., Marcinkowska, E., Restaurator, 2000, 21, 138-157, https://doi. org/10.1515/REST.2000.138.

4. Fessas, D., Schiraldi, A., Tenni, R., Zuccarello, L., Bairati, A., Faccini, A., Thermochim Acta, 2000, 348, 129-137, https://doi.org/10.1016/ S0040-6031(00)00350-6.

5. Dolgin, B., Bulatov, V., Schechter, I., Rev Anal Chem, 2009, 28, 3-4, 151-307, https://doi. org/10.1515/REVAC.2009.28.3-4.151.

6. Dolgin, B., Bulatov, V., Schechter, I., Anal Bioanal Chem, 2007, 388, 5, 1885-1896, https://doi.org/10.1007/s00216-007-1410-0.

7. Dzendzeliuk, L., Loda, L., Stempitska, Y., The theory and practice of material and artistic culture, Proceedings, Kharkiv State Academy of Design and Fine Arts, Ukraine, 2006.

8. Ignatov, A., Shlyakova, L., Sarycheva, V., Dorofeev, M., patent no 260074 SSSR, 1980, 2471699/28-12.

9. Kol, L., Succulent and suede tanning, Moscow, ONTY, 1932.
10. Monsheimer, R., Pfleiderer, E., patent no 4310328 US, 1982, 122, 04.

11. Adakina, N., Kolesnyk, T., Andreyeva, O., Herald of Khmelnytskyi National University, 2018, 1, 257, 187-192.

12. Kolesnyk, T.O., Andreyeva, O.A., Nikonova, A.V., Savchuk, O.M., Baltic Polymer Symposium 2018, Programme and proceedings, Latvia, 2018.

13. Chursin, V., L'vova, A., Safronov, D., Patent 2314525 RU, 2008, 206117369/12.

14. Bradford, M., Anal Biochem, 1976, 86, 193200, https://doi.org/10.1086/291994.

15. Nykolaychyk, V., Moyn, V., Kyrkovskyy, V., Laboratornoe case, 1991, 10, 13-18.

16. Paula, H., Stephan, K., Edouard, E., J Liq Chromatogr Relat Technol, 2012, 35, 29232950, https://doi.org/10.1080/10826076.20 12.743724 .

17. http://www.bio-rad.com/webroot/web/pdf/ Isr/literature/Bulletin 6040.pdf.

18. Kennedy, C., Wess, T., Restaurator, 2003, 24, 2, 61-80, https://doi.org/10.1515/ REST.2003.61.

19. Weiss, T., Orgel, J., Thermochim Acta, 2000, 365, 1, 119-128, https://doi.org/10.1016/ s0040-6031(00)00619-5.

20. Brodsky, B., Ramshaw, J., Matrix Biol, 1997, 15, 545-54, https://doi.org/10.1016/S0945053×(97)90030-5.

21. Zhang, D., Chippada, U., Jordan, K., Ann Biomed Eng, 2007, 35, 1216-1230, https:// doi.org/10.1007/s10439-007-9296-8.

22. Ghioni, C., Hiller, J., Kennedy, C., Aliev, A., Odlyha, M., Boulton, M., Wess, T., J Lipid Res, 2005, 46, 9, 2726-2734, https://doi. org/10.1194/jlr.M500331-JLR200. 
23. Stirlic, M., Kralj Cigic, I., Rabin, I., Kolar, J., Pihlar, B., Cassar, M., Polym Degrad Stab, 2009, 94, 886-890, https://doi.org/10.1016/j. polymdegradstab.2009.03.003.
(C) 2019 by the author(s). Published by INCDTPICPI, Bucharest, RO. This is an open access article distributed under the terms and conditions of the Creative Commons Attribution license (http:// creativecommons.org/licenses/by/4.0/). 